\title{
The Student Entrepreneurship Readiness in Vocational Schools
}

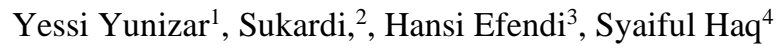 \\ \{yessi.yunizar@gmail.com \} \\ ${ }^{1}$ Faculty of Engineering, Universities Negeri Padang, Indonesia
}

\begin{abstract}
Technological developments cause huge challenges and threats to humans so humans must actively adapt and solve problems. Industrial Revolution 4.0 is a real form of the presence of various problems if they don't have competence in one field. Many layoffs and termination of cooperation, but also presents a new form of work with new expertise that causes the world of education must prepare graduates who have competence and entrepreneurial spirit to be independent. This qualitative research was conducted at a vocational high school by interviewing grade XI students. As many as $81.48 \%$ of students prepare themselves cognitively by learning in their preferred field. $7.4 \%$ of students stated that they had been directly involved in entrepreneurship. Besides that, $77.78 \%$ of students don't have entrepreneurial family backgrounds. It can be concluded, the readiness of students' entrepreneurship has existed in the form of improving their knowledge, but hasn't been directly involved in entrepreneurship.
\end{abstract}

Keywords: Entrepreneurship, Student, readiness.

\section{Introduction}

Changes that occur in life after entering the era of the industrial revolution 4.0 are felt in human life [1]. Not only in the form of physical changes but also non-physical. Physical changes such as the loss of various electronic devices and integrated in a complex device such as a smartphone have combined radio, camera, recorder type, $\mathrm{mp} 3$, telephone, game, and others in one hand. This change causes damage to the world of work for several fields and presents other types of work that are more complex in real terms. While in terms of nonphysical changes in human behavior, habits, and ways of thinking [2]. Besides that, the number of unemployed people in Indonesia is still 7 million as of March 2019 [3].

Changes in culture and direction of education need to be considered because changes after entering the industrial revolution 4.0 are not uncommon [4]. Indonesian education is still uneven, the distribution of teachers has not been balanced, and Indonesia's educational infrastructure is still lacking.

Not to mention touching the issue of entrepreneurship [5]. The latest data, as of March 2019 , Indonesian entrepreneurs have indeed reached 8 million people or $2 \%$ of the population, but they are still inferior to Singapore which is 7\% and Malaysia which is 5\% [6,7]. 
Entrepreneurship research has not been done much in detail by people. Basically, entrepreneurship is not just about selling, but more about management, independence, creativity, and innovation [8]. Research on entrepreneurship in schools has also not been done much, even though schools are an important part of instilling entrepreneurial values in addition to student competence [9].

So, it is necessary to do research in vocational schools about the readiness of students in entrepreneurship. It is hoped that the true reality of student entrepreneurship readiness and can help policy makers in the world of education to direct the education curriculum for students towards competent graduates who are well prepared for work and entrepreneurship readiness.

\section{Theory}

\section{Entrepreneurship}

Entrepreneurship is an ability to create creativity in building innovation in solving life's problems to gain profit and benefit [10], [11]

\section{Education}

Education is the process of facilitating learning, or obtaining knowledge, skills, values, beliefs, and habits [12], [13].

\section{Readiness}

Readiness is the condition or condition that is being prepared (person, system, or organization) to deal with the situation and take the appropriate sequence of actions. This is based on planning and capital in acting on a matter [14], [15].

\section{Research Method}

This descriptive research was done by interviewing students in vocational school. They were asked about their knowledge about entrepreneurship, readiness of it, their background, and their preparation to face the challenge of live in entrepreneurship

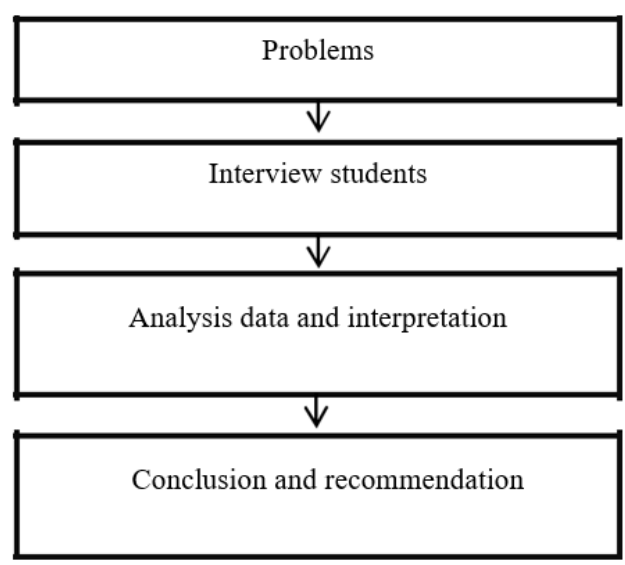

Figure 1. Flow of Research 
Pada In Figure 1, it can be seen that this research starts from a problem, then an analysis is carried out so that ideas are found to conduct interviews with vocational students. Previous interviews have been formulated in terms of questions that refer to knowledge students related to entrepreneurship, the preparation for facing the challenges of the times, family background, and understanding of entrepreneurship.

The results of the interview are recapitulated and analyzed to obtain interpretation and direction of conclusions.

\section{Result And Discussion}

\section{Result}

This research has produced field data on the readiness of vocational student entrepreneurs in facing challenges and threats to the progress of world development. Retrieval of data is divided into three areas of student readiness in entrepreneurship, namely the cognitive, affective, and psychomotor fields. These results can be seen in Table 1 .

Table 1. Three areas of vocational student entrepreneurship readiness.

\begin{tabular}{cccc}
\hline \multicolumn{4}{c}{ Result } \\
\hline Value & Cognitive & Affective & Psychomotor \\
\hline $\begin{array}{c}\text { Value or } \\
\text { Score }\end{array}$ & 81,48 & 72,00 & 7,40 \\
\hline
\end{tabular}

Table 2. Background \& experience

\begin{tabular}{ccc}
\hline \multicolumn{3}{c}{ Result } \\
\hline Value & $\begin{array}{c}\text { Family } \\
\text { background }\end{array}$ & Student experience \\
\hline $\begin{array}{c}\text { Value or } \\
\text { Score }\end{array}$ & 77,78 & 18,52 \\
\hline
\end{tabular}

Table 1 shows a significant difference between vocational students' readiness on the cognitive side of $81.48 \%$ and affective $72.00 \%$, while only $7.40 \%$ in the psychomotor domain. Table 2 shows the condition of students' backgrounds and experiences of students in entrepreneurship.

\section{Discussion}

The magnitude of the challenges and threats of the industrial revolution 4.0 has been realized by vocational students, this is known from the magnitude of the spirit of learning in preparing themselves to face current technological advances. In the interview, it is known that vocational students know about entrepreneurship and on average they try to increase their knowledge about entrepreneurship. In accordance with the latest references, it is stated that there is an increase in the interest of Indonesian students about entrepreneurship and in general Indonesian entrepreneurs are increasing at this time reaching $2 \%$ of the population (8 million people). But that number is still less than Singapore (7\%) and Malaysia (5\%). The proof, though in a way cognitive students want to learn about entrepreneurship but many of them do 
not take an entrepreneurial attitude, let alone directly involved in entrepreneurship. This gap means that there are problems that must be corrected quickly together. This must be a special study for the world of education which incidentally is the front line in preparing graduates of the world of education for graduates who are competent and have entrepreneurial skills. The world of education must look at the gap between cognitive, and the lack of affective and psychomotor. Students in entrepreneurship with this comprehensive and create opportunities for students to directly engage in entrepreneurship in the form of programs and cooperation that can train students to be creative in entrepreneurship. Besides that, certainly a policy or a new direction for curriculum that can be applied according to the needs of students is needed and to answer the challenges and threats of technological developments such as the era of the industrial revolution 4.0 and the coming industrial revolution.

\section{Conclusion}

The results of this study can be concluded that:

- Students know about entrepreneurship and they have prepared their self to increase it to face the threat and challenge in industrial revolution 4.0 (cognitive)

- Student were not active in (affective and psychomotor) entrepreneurship actions.

- Mean of students were not from entrepreneur family

- Students area did not also contribute to influence student to build their action in entrepreneurship.

- Indonesia government must set a new program to make student have many chances to improvetheir potential in psychomotor of entrepreneurship.

\section{Acknowledgments}

Thank you to people who have helped and contributed to complete this journal.

\section{References}

[1] Ahmad Hidayatno, A. R. (2018). Industry 4.0 Tecnology Implementation Impact to Industrial Sustainable Energy in Indonesia: A Model Conceptualization. Elsevier, 227-233.

[2] Wellyngton Silva de Amorim, A. B. (2019). Urban Challenges and Opportunities to Promote Sustainable Food Security. Elsevier, 1-6.

[3] Roosyana, R. (2019). Masih Ada 7 JutaPengangguran di Indonesia. Jakarta: Beritagar.id.

[4] Rahayu, N. (2019, may 7). Mengenal Revolusi Industri dari 1.0 hingga 4.0. Retrieved August 12, 2019, from Wartaekonomi: https://www.wartaekonomi.co.id/read226785/ mengenal-revolusiindustri-dari-10-hingga-40.html

[5] Dutta, S. (2019). Seeing parochially and acting locally: Social exposure, problem identification and social entrepreneurship. Elsevier.

[6] Siregar, T. (2019). Jumlah Wirausaha di Indonesia Tembus 8 Juta Jiwa. Jakarta: rri.co.id

[7] Walter. (2018). Jumlah Pengusaha di Indonesia Meningkat. Jakarta: KoinWorks.com.

[8] Isti Raafaldini Mirzanti, T. S. (2015). Mapping on Entrepreneurship Policy in Indonesia. Elsevier, 346-353.

[9] Triyono, B. (2015). The Indicators of Instructional Design for E- learning in Indonesian Vocational High Schools. Elsevier, 54-61. 
[10] Ferreira, N. M. (2019, May 12). What Is Entrepreneurship? Entrepreneur Definition and Meaning. Retrieved Augustus 11, 2019, from Oberlo: https://www.oberlo.com /blog/what-isentrepreneurship\#

[11] Johan Wiklund, B. N.-d. (2019). Entrepreneurship and well-being: Past, present, and future. Journal of Business Venturing-Elsevier, 579-588.

[12] Sharma, V. K. (2019, January 20). Importance of Education. Retrieved Augustus 12, 2019, from Klient Solutech: http://www.klientsolutech.com/importance-of-education-in-life/

[13] Long, N. V. (2019). Financing higher education in an imperfect world. Economic of Education Review, 23-31.

[14] N, P. (2013, April 28). Readiness. Retrieved Augustus 12, 2019, from Psychologyy Dictionary: https://psychologydictionary.org/ readiness/

[15] Kylie A Rymanowicz, K. J. (2019). School Readiness. Reference Module in Neuroscience and Biobehavioral Psychology, 54 